\title{
Prostorski vidiki načrtovanja logističnih središč: primer gospodarskega središča Feniks v Posavju
}

Prostorsko načrtovanje logističnih središč izhaja iz posebnih prostorskih in infrastrukturnih zahtev, ki jih pogojujeta obseg in želena pretočnost prometa. Prostorske in okoljske omejitve na običajnih pretovornih lokacijah silijo logistične dejavnosti v iskanje takšnih območij, ki omogočajo nemotene širitve in praktično neomejene prometne tokove. Posledica te težnje je suburbanizacija z vsemi prostorskimi in okoljskimi posledicami. Prispevek, v okviru zavedanja neponovljivosti posamezne lokacije, opozarja na pomen celovitosti in pravočasnosti prostorskega in okoljskega načrtovanja logističnih središč. V tem smislu se oblikovanje prostorskega koncepta, na jasnih prostorskih ciljih, transparentnih analitičnih izhodiščih in ustrezno pro- storsko regulacijo, izkazuje kot zahteva prostorskega načrtovanja logističnih središč. Sočasno je, upoštevajoč zapletenost prostorskih ureditev, izpostavljen tudi pomen prostorske kohezije, ki se izraža kot prostorska identiteta, prostorska kakovost in prostorska učinkovitost.

Ključne besede: prostorsko načrtovanje, logistična središča, prostorska kohezija, prostorska regulacija, gospodarsko središče Feniks v Posavju 


\section{Uvod}

Navezovanje na prometne koridorje, vozlišča različnih prometnih sistemov, omrežja središč ter izvore in cilje tovora so zagotovo tista izhodišča, ki odločilno vplivajo na umeščanje logističnih središč. Gre za samoumevno osnovo, ki jo praksa ustrezno obvladuje, zato jo prispevek pušča ob strani. Prispevek se ukvarja $s$ prostorsko načrtovalsko dimenzijo problematike, ki je kljub hitremu razvoju dejavnosti, ki promovirajo razcvet logistike in z njo povezanih potreb po umeščanju logističnih središč, dokaj slabo razvita. Načrtovanje logističnih središč in upravljanje tokov tovornega prometa še vedno ostaja (tudi v evropskem merilu) predvsem domena investitorjev in z njimi povezanih ekonomskih interesov. Celovite razvojne strategije in instrumenti prostorskega načrtovanja tako samo sledijo njihovim željam, namesto da bi konstruktivno upravljali in usmerjali prostorski razvoj.

Prispevek se osredotoča na postopke prostorskega načrtovanja in tiste vidike umeščanja razvojnih območij, ki se jim pogosto posveča premajhna pozornost ali se jih $\mathrm{v}$ proces načrtovanja vključuje prepozno. Članek izhaja iz izkušenj priprave državnega prostorskega načrta za gospodarsko središče Feniks v Posavju, ki ga je na pobudo ministrstva za gospodarstvo in po naročilu Javne agencije Republike Slovenije za podjetništvo in tuje investicije pripravilo podjetje LUZ, d. d.

Priprava državnega prostorskega načrta temelji na teoretskih izhodiščih kompleksnega prostorskega načrtovanja (angl. comprehensive planning). Zavedajoč se slabosti klasičnega kompleksnega načrtovanja, ki so vodile v razvoj nekaterih drugih oblik načrtovanja (Campbell in Fainstein, 1998), ter upoštevajoč problematiko dosedanje priprave državnih prostorskih aktov (Zavodnik Lamovšek idr., 2008; Mlakar, 2006) in aktualno evropsko doktrino prostorske kohezije (Free University of Brussels - IGEAT, 2006) je postavljen metodološki okvir priprave naloge, ki je prilagojen posebnostim prostorskonačrtovalskega problema. Pri oblikovanju tega okvira je posebna pozornost namenjena varstvu okolja kot dinamičnemu procesu, ki naj bo nenehno, na različnih ravneh, z različno natančnostjo, z različnimi, toda metodološko in vsebinsko povezanimi postopki integriran s postopkom urejanja prostora. Tako povezovanje je $\mathrm{v}$ tujini dobilo izraz $\mathrm{v}$ opredelitvi okoljskega načrtovanja (angl. environmental planning). Sonaravna ocena nacionalnih razvojnih projektov (Plut, 2007) s področja gospodarstva, ki naj bi bila prva prioriteta RS, poudarja, da lahko obvladljivost okoljkkih pritiskov predvidenih projektih dosežemo le s primerno mikrolokacijo in sonaravno zasnovo območij, med katera sodi tudi projekt gospodarskega središča Feniks v Posavju.

Kljub posebnostim obravnavanega gospodarskega središča so predlagana izhodišča lahko usmeritev za umeščanje, načrto- vanje, reguliranje in upravljanje drugih gospodarskih ter logističnih središč na regionalni ravni. Sočasno želi prispevek vzpostaviti globljo znanstveno debato o izboljšavah predlaganega postopka ter prispevati k izboljšanju zakonodajnega okvira priprave prostorskih aktov za tovrstne prostorske ureditve.

\section{Razvoj mreže logističnih središč}

Prostorska organizacija ekonomske aktivnosti se je med desetletji spreminjala, upoštevajoč strukturne spremembe, nove tehnologije in globalizacijske tokove. Izmenjava dobrin, kot konstanta ekonomske dejavnosti, se je po industrijski revoluciji okrepila in v zadnjem času dosegla globalne razsežnosti. Industrializacija in v tem smislu geografija proizvodnje se je v splošnem razvijala glede na izboljšave v dostopu, ki jih je sprva pogojeval dostop do morja, kasneje pa celinski vodni promet in razvoj železnic, ki so se navezovale na cestne tovorne poti (Hesse, 2008).

Razvoj informacijske in komunikacijske tehnologije je sedaj ključno vodilo v evoluciji ekonomskega razvoja in z njim povezane fizične distribucije blaga. Posledica tega je napačna predstava logistične dejavnosti kot virtualnih tokov, ki nimajo fizičnega odgovora v konkretnem prostoru. $S$ tem se zanemarja prostorska dimenzija tovornih tokov, njihov bistveni vpliv na urbani razvoj in zasnovo namenske rabe prostora na lokalni in tudi regionalni ravni.

Velikost in pretočnost prometa, skupaj s prostorskimi in urbanističnimi omejitvami, silita prostorsko » potratne « namenske rabe v iskanje takšnih lokacij, ki omogočajo velike širitve, nemotene prometne tokove in ponujajo nizke cene zemljišč. $\mathrm{V}$ tem preseku se suburbani prostor $\mathrm{z}$ vidika poteka dejavnosti tega tipa ponuja kot vsaj navidezno najugodnejša rešitev. Suburbanizacija oziroma regionalizacija logistične dejavnosti pa vodi v prostorske in predvsem programske spremembe. Pojem mesta kot središča trgovanja in izmenjave dobrin se opredeljuje na novo, kar se fizično kaže v zasnovi namenske rabe ter razpršenosti mestne strukture in tudi krajine. Posegi zunaj poselitvenih območij zato zahtevajo oblikovanje jasnih konceptov načrtovanja in kasnejšega upravljanja (reguliranja) takšnih območij.

\section{Opredelitev ciljev}

Nujnost oblikovanja jasnih ciljev in prostorskih konceptov ter usklajenih prostorskih rešitev izhaja iz domneve o prostorskem načrtovanju kot aktivnosti, s katero ustvarjamo red in gotovost. Cilji prostorskega razvoja se morajo prek analize jasno izraziti $\mathrm{v}$ prostorskem konceptu načrtovanega logističnega središča, ki naj odgovori na prostorsko načrtovalna vprašanja, kot so npr.:

- kako se logistično središče vključuje v širši razvojni koncept (občine, regije, države); 
- na katere dejavnosti se navezuje razvoj logističnega središča, katere dejavnosti se bodo $\mathrm{v}$ povezavi z logističnim središčem razvijale, kakšne so prostorske in okoljske posledice tega vzporednega razvoja;

- kako bo izgradnja logističnega središča vplivala na razvoj poselitve in druge dejavnosti v prostoru;

- kako bo izgradnja logističnega središča vplivala na daljinske in lokalne prometne tokove, kakšne so potrebne prilagoditve prometnega omrežja;

- kakšni bodo okoljkki vplivi logističnega središča in kako bodo omiljeni;

- kaj še rešujemo poleg zgoraj naštetega katere dejanske probleme, probleme, ki so ovira do realizacije ciljev, ali morebitne probleme, ki jih prinašajo nove prostorske ureditve.

Prostorski cilji se torej nanašajo na vse vidike razmišljanja o prihodnosti prostora in tudi na vse ravni urejanja prostora, od strateške do izvedbene ravni ureditve posameznih, najmanjših prostorsko zaključenih enot. Izkazuje se dejstvo, da načrtovanje logističnega središča ne more več vnaprej izhajati iz podatkov prometnih tokov in tokov blaga. Poglavitna je ocena vloge logistike kot dejavnosti in pričakovanega oziroma želenega obsega tovornega prometa v posameznem urbanem oziroma regionalnem okolju (Hesse, 2008). V tem kontekstu se nato lahko zasnuje funkcijska in prostorska logika mreže tovorni tokov ter z njimi povezanih mogočih lokacij logističnih središč. Na tako postavljeno izhodišče se delijo zahteve in pričakovanja investitorjev ter predvideni učinki, ki bi jih uresničitev projekta prinesla v določeno okolje. $S$ tem je v načrtovanje središč vključena posebnost posamezne lokacije. $V$ kasnejših stopnjah se na osnovi primerjalnih študij postopno preide $\mathrm{v}$ izbor najboljše in tako zmanjša tveganost investicij.

Pri opredeljevanju ciljev se v zadnjem času vse bolj izpostavlja prostorska kohezija, ki jo je mogoče smiselno uporabiti tudi pri načrtovanju logističnih središč kot kompleksno prostorsko ureditev, za katero je značilna povezljivost ter večplastni vplivi na prostor in družbo v njem. Prostorsko kohezijo je mogoče obravnavati kot prostorsko dimenzijo trajnostnega razvoja, ki medsebojno povezuje ekonomski, socialni in okoljski vidik (Free University of Brussels - IGEAT, 2006). Prostorsko dimenzijo, ki je neposredno povezana tudi s konkurenčnostjo logističnega središča, lahko torej izrazimo kot (Free University of Brussels - IGEAT, 2006; Zavodnik Lamovšek idr., 2008):

- prostorsko identiteto, ki v večini primerov opredeljuje razvoj, ker določa možnosti lokalnega produkcijskega sistema;

- prostorsko kakovost, ki jo lahko opredelimo kot triado vidne privlačnosti, funkcionalnosti in prijetnosti bivanja oziroma dela, ter

- prostorsko učinkovitost, ki pomeni razmerje med učinki in stroški, s kategorijami, ki niso izključno gospodarske.

\section{Analiza}

Govoriti o pomenu analize se morda zdi odveč, ampak praksa kaže, da ob pogostem deklarativnem določanju lokacij to ven-

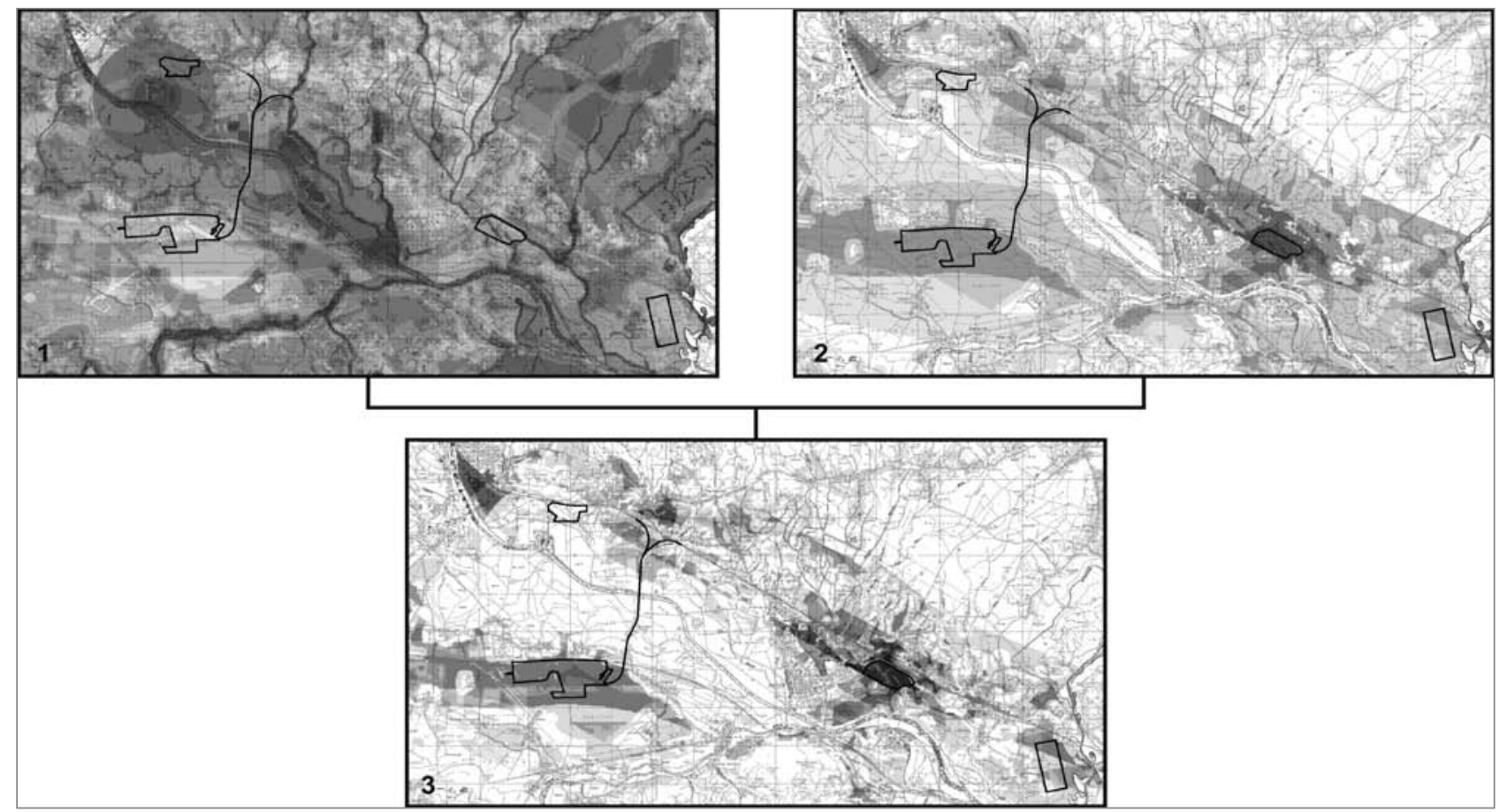

Slika 1: 1 - Analiza ranljivosti (temneje - ranljivejše); 2 - Analiza privlačnosti (temneje - privlačnejše); 3 - Analiza ustreznosti prostora (temneje ustreznejše) za logistično središče v okviru gospodarskega središča Feniks v Posavju, z označenimi možnostmi lokacij središča (vir: Mlakar, 2008). 
darle ni samoumeven začetni korak prostorskega načrtovanja. Načrtovalno analizo je mogoče opredeliti kot zbirko odgovorov na vprašanja, ki so povezana z uresničevanjem prostorske ureditve oziroma razreševanjem tega problema. Najpomembnejši problem, ki naj bi ga razrešili pri načrtovanju logističnega središča, je iskanje ustreznega mesta $\mathrm{v}$ prostoru. $\mathrm{Ob}$ tem se srečujemo z usklajevanjem razvojnega in varovalnega vidika.

Najpomembnejši preventivni varstveni ukrep je optimizacija lokacije posega saj se z ustreznim lociranjem dejavnosti praviloma zmanjšuje tudi vpliv na okolje. Kot eno najuspešnejših metod varovalnega načrtovanja je treba (ponovno) izpostaviti analizo ranljivosti oziroma ugotavljanje občutljivosti prostora, metodo (mehanizem, opravilo, postopek), s pomočjo katere prek vrednotenja potencialnih vplivov logističnega središča na posamezne prostorske sestavine ugotovimo ranljivejše oziroma občutljivejše dele prostora in predvsem opredelimo tiste dele, $\mathrm{v}$ katere naj obravnavanega posega ne bi umestili. Ranljivost torej še ne pove, kje v prostoru naj bi postavili logistični center. Da bi opredelili mogoča mesta za logistični center, je treba prostor vrednostno členiti tudi v pogledu meril privlačnosti prostora. $\mathrm{Ta}$ analiza odkriva dele prostora, $\mathrm{v}$ katerih naj bilo delovanje logističnega središča tehnološko in ekonomsko optimalno. Kot eden od najpomembnejših dejavnikov pri izbiri ustrezne lokacije gospodarskega središča v prostoru se poleg kriterijev dostopnosti in možnosti nadaljnjih širitev izpostavlja tudi razdelitev predvidenih delovnih mest med delavce (Nared, 2007).

Soočenje obeh vidikov v okviru analize ustreznosti prostora odkriva mogoče (alternativne) lokacije, ki omogočajo uresničevanje ciljev razvoja logistične dejavnosti in so hkrati okoljsko sprejemljive.

\section{Oblikovanje in primerjava možnosti}

Oblikovanje možnosti in omogočanje izbir med njimi je primarni pogoj optimizacije procesa odločanja (Chechile in Carlisle, 1991). Bistvo odločanja je izbiranje med možnost$\mathrm{mi}$, pa naj gre za urejanje prostora, varstvo okolja, varstvo kulturne dediščine, ekonomijo ali povsem običajno odločanje $\mathrm{v}$ vsakodnevnem življenju. Za uspešnost presoje sprejemljivosti prostorske ureditve je odločilno, da je predlog posega podan kot možnost (različicah, scenarijih ipd.). V prostoru se srečuje več različnih, lahko popolnoma nasprotujočih si interesov (razvojnih, varstvenih, parcialnih interesov različnih skupin $\mathrm{v}$ prostoru ...), hkrati pa ima nosilec posega praviloma na voljo več izbirnih možnosti za dosego zastavljenih ciljev, vsaka od njih pa različno ekonomsko in tehnično zahtevnost, vplive na okolje, družbeno sprejemljivost. $\mathrm{V}$ procesu opredelitve in analize možnosti je mogoče ugotoviti, kako so ti interesi lahko upoštevani oziroma katera od možnosti v največji meri ustreza opredeljenim ciljem.

Vprašanje možnosti se navezuje na eno temeljnih domnev uspešnosti (okolje)varstvenega delovanja v okviru prostorskega načrtovanja, to je da se varstvene zahteve v presojah vplivov na okolje lahko uveljavijo samo prek izbire možnosti, ki je za okolje najmanj škodljiva (Marušič, 1993).

Možnosti posega pomenijo različne možnosti uresničitve $\mathrm{v}$ osnovi istega nameravanega posega. Pri logističnem središču pomeni to različne lokacije in/ali različne urbanistične ali tehnološke rešitve tega središča. Mogoči posegi pa pomenijo že v osnovi različne možnosti uresničitve končnega cilja. Pri logističnem središču lahko takšne možnosti pomenijo drugačne oblike distribucije tovora. Mogoči posegi so torej možnosti strateških oziroma zgodnejših ravni načrtovanja.

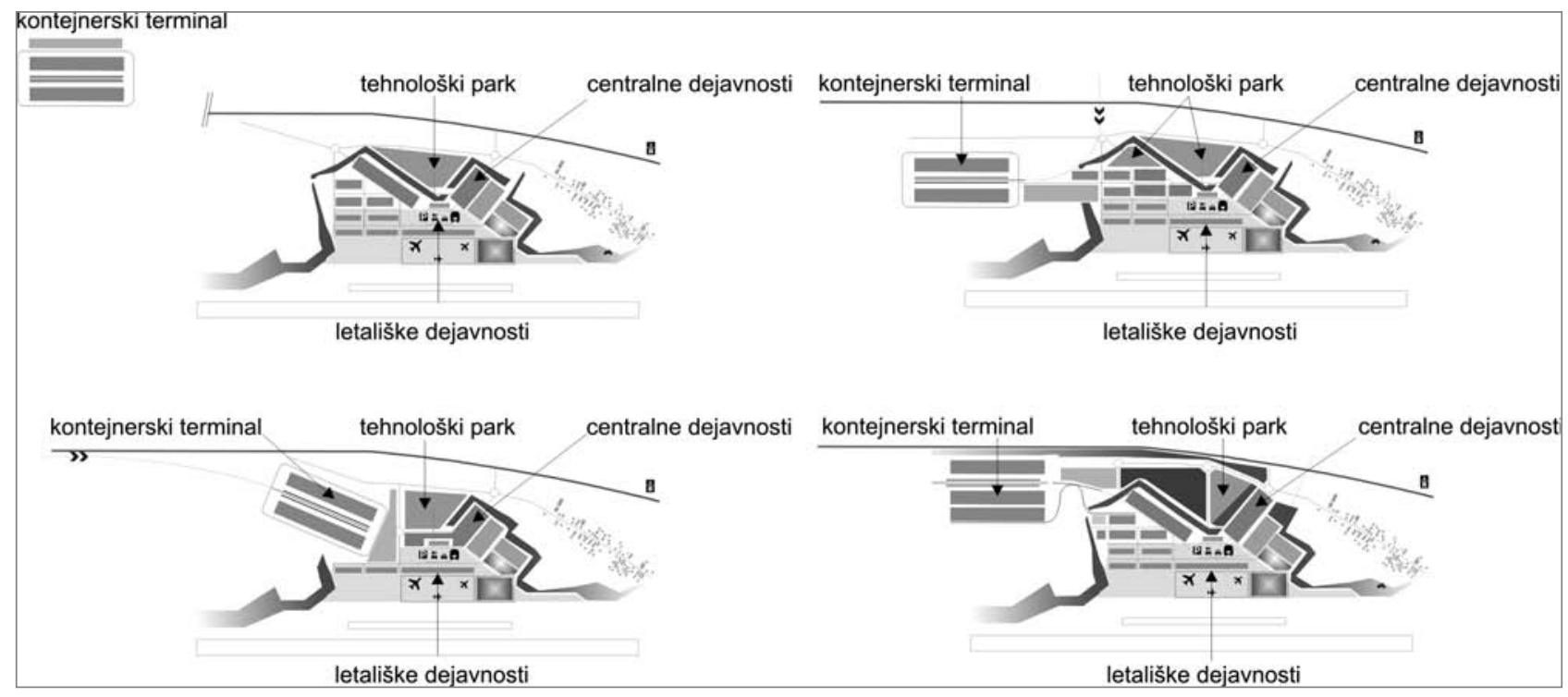

Slika 2: Možnosti urbanističnih in prometnih rešitev osrednjega dela gospodarskega središča Feniks v Posavju (vir: Mlakar, 2008) 
Možnosti logističnih središč je mogoče ločevati na:

- možnosti, ki se razlikujejo po posegu (nameri, programu), ki se nanašajo na to, $\gg k a j \ll v$ povezavi $z$ razvojem logistične dejavnosti umestiti v določeno območje;

- možnosti, ki se razlikujejo po lokaciji v osnovi istega posega, ki se nanašajo na vprašanje, » kje « umestiti načrtovani logistični center;

- možnosti, ki se razlikujejo po načinu rešitev posega na isti lokaciji in so odgovor na vprašanje, »kako « umestiti poseg na izbrani lokaciji, in

- možnosti, ki se razlikujejo po obsegu posega, pri katerem je predmet obravnave, »v kolikšni meri « naj se izkoristi določeno razpoložljivo območje.

V skladu z načrtovalsko prakso zadnjih let je primerjava možnosti logističnih središč praviloma osredotočena na primerjavo štirih osnovnih vidikov:

- okoljskega vidika, ki sovpada s pripravo okoljskega poročila o celoviti presoji vplivov na okolje;

- prostorskega vidika vidika skladnosti z regionalnim in urbanističnim razvojem;

- gradbeno-tehničnega vidika vidika funkcionalnosti logistične dejavnosti, ter

- ekonomskega vidika, v okviru katerega se izračunavata investicijska vrednost in ekonomska učinkovitosti.

Sočasno se v postopku prostorskega načrtovanja praviloma ugotavlja tudi sprejemljivost $\mathrm{v}$ (lokalnem, širšem) družbenem okolju. Gre za v osnovi uveljavljen postopek, zato ga ne ponavljamo. Opozarjamo pa na prenovo tega postopka, upoštevajoč $\mathrm{v}$ uvodu izpostavljeno jasnejše opredeljevanje ciljev in ugotavljanje oziroma uresničevanje prostorske kohezije (Zavodnik Lamovšek idr., 2008).

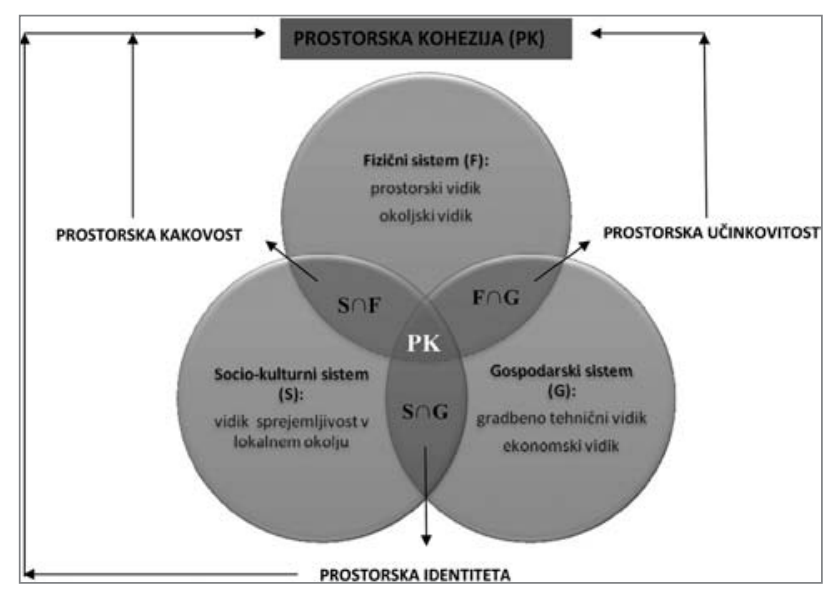

Slika 3: Razporeditev petih vidikov vrednotenja v študiji različic glede na Vennov diagram prostorske kohezije (vir: Zavodnik Lamovšek, 2008; prirejeno po Free University of Brussels - IGEAT, 2006, in Radej, 2008).

\section{Oblikovanje koncepta}

Premik v zavedanju posebnosti in pravzaprav neponovljivih lastnosti posamezne lokacije pomeni novo stopnjo v razvoju načrtovanja logističnih središč. Oblikovanje konceptualne rešitve območja s pravilno notranjo organizacijo in vpetostjo v širši prostor temelji na natančnih ekonomskih napovedih, poznavanju prostorskih lastnosti območja in predvidenega programa. Za načrtovalca je najpomembnejše poznavanje vnaprej določenega programa. Programska dorečenost odgovarja na pretežno vsa prostorska vprašanja, omogoča pravilno coniranje, vodenje prometne mreže in pravilno zasnovo komunalnih ureditev ter zmanjšuje možnost napak v regulaciji posameznih con. Konceptualna rešitev se mora ravnati po grajenem in tudi negrajenem kontekstu ter reševati notranjo organizacijo središča. Postavljeni koncept vnaprej nakazuje coniranje in daje osnove za regulacijo območja s pomočjo urbanističnih parametrov.

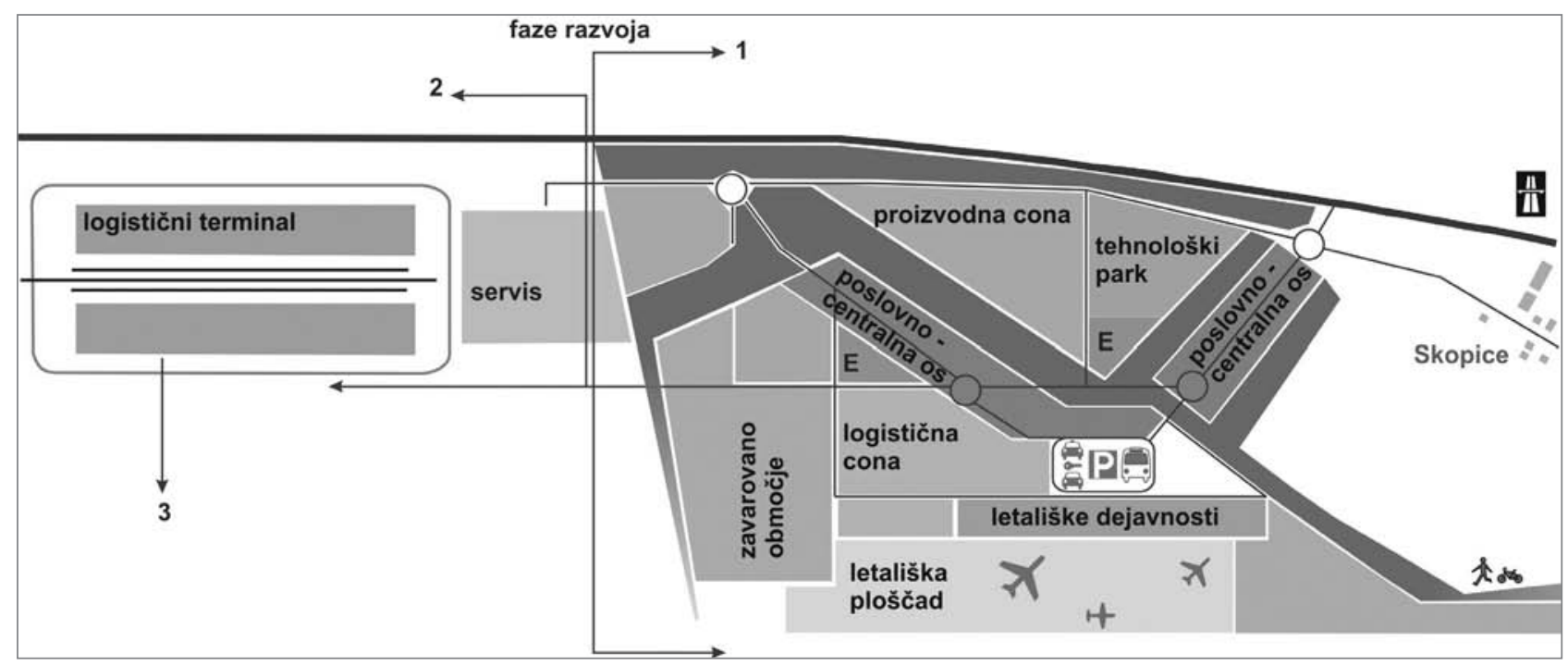

Slika 4: Koncept gospodarskega središča Feniks (vir: Mlakar, 2008) 
Temeljna načrtovalska izhodišča pri oblikovanju koncepta logističnega središča so:

- ureditev racionalnih tovornih cestnih in železniških poti z možnostjo izvedbe v več stopnjah;

- oblikovanje takšnega prostorskega koncepta, ki omogoča izvedbo v več stopnjah, ki pa niso nujno časovno sosledne;

- programska delitev na več enot, ki se vsebinsko in infrastrukturno med seboj navezujejo ter dopolnjujejo;

- upoštevanje naravnih in grajenih značilnosti ter omejitev iz naravo- in kulturnovarstvenega vidika;

- morebitno poseganje na kmetijske površine mora $\mathrm{v}$ čim večji meri zagotavljati sklenjenost in celovitost kompleksov kmetijskih površin;

- racionalna raba energije;

- upoštevanje ukrepov za omejitev vplivov na okolje;

- zasnova središča mora v čim večji meri upoštevati že sprejete ureditve.

\section{Regulacija logističnega središča}

Logistična središča so tipičen primer materializacije gospodarske propulzivnosti in odzivnosti prostorskih rešitev na zahteve trga. Zasledovanje takšnih načel zahteva oblikovanje prilagodljive regulacije, ki lahko z minimalnim številom parametrov korektno usmerja prostorski razvoj. Pri tem je treba opredeliti:

- zasnovo namenske rabe oziroma členitev na površine funkcionalno kompatibilnih rab s pogoji arhitekturnega in krajinskoarhitekturnega oblikovanja,

- prometno mrežo,

- komunalno opremljenost.

Odprtost sistema daje večje možnosti prilagoditve. Število mogočih ureditev je zato zelo veliko, kar je zelo pomembno, če se ne načrtuje za znanega investitorja.

\section{1 Členitev na prostorske enote s pogoji arhitekturnega in krajinskoarhitekturnega oblikovanja}

Logistična središča navznoter niso »monofunkcionalna « območja. Poleg osnovnih dejavnosti, ki se vežejo na dejavnosti transporta, skladiščenja in distribucije, se vanje umešča večje število spremljajočih dejavnosti »javnega « oziroma osrednjega značaja (carina, pisarne, pošta, banka ...). Da bi se izognilo mešanju nekompatibilnih dejavnosti, se območje deli na posamezne funkcionalno in prostorsko zaključene enote. Definiranje prostorskih enot kot osnovnih gradnikov pomeni poenostavitev v načinu prostorskega načrtovanja in reguliranja, hkrati pa takšna delitev vodi v optimalno delovanje središča in večanje sinergijskih učinkov predvidenih dejavnosti.

Prostorska enota nosi zapis enotne namenske rabe, dopustnih dejavnosti in objektov ter daje maksimalne dopustne faktorje glede pozidanosti, izkoriščenosti in višine stavb. Navznoter dopušča mešanje, kar je eden izmed osnovnih načel sodobnega mesta, vendar znotraj okvira kompatibilnih dejavnosti. Notranjo heterogenost dopustnih dejavnosti in objektov navzven poenotijo oblikovalski kriteriji. Prostorska enota hkrati zagotavlja programsko heterogenost, vsebinsko in infrastrukturno navezovanje ter enotno morfološko zgradbo.

Regulacija območij se razlikuje glede na predlagano namensko rabo posamezne enote. Da bi se izognilo prenormiranosti (togosti) prostorskih enot, je najpomembnejša kombinacija dveh od treh bistvenih faktorjev oziroma prostorskih pogojev: faktor izrabe, faktor zazidanosti in maksimalna dovoljena višina. Če sta definirana dva od treh pogojev, imamo dovolj natančen prostorski okvir, hkrati pa dovolj velik manevrski prostor, da je mogoča umestitev objektov različnih dejavnosti in tipologij. Zaradi narave proizvodne dejavnosti, ki zahteva predvsem

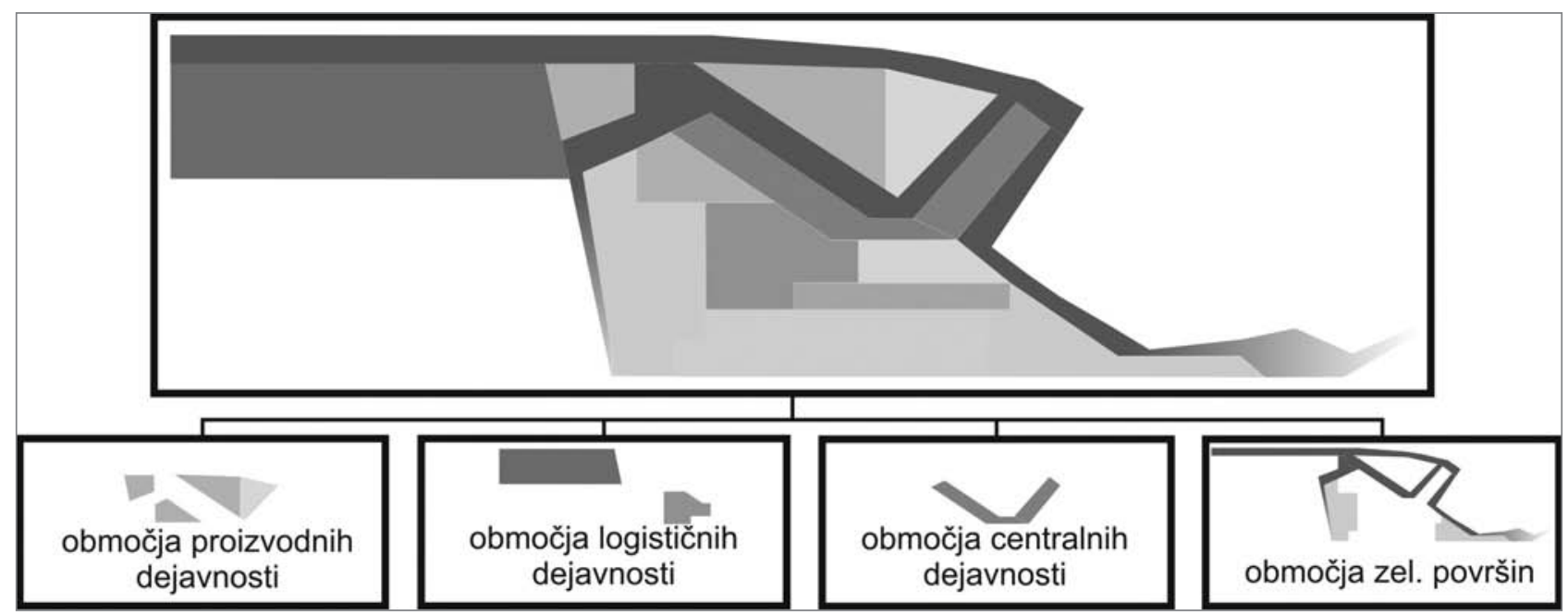

Slika 5: Območja enotnega urejanja za gospodarsko središče Feniks (vir: Mlakar, 2008). 


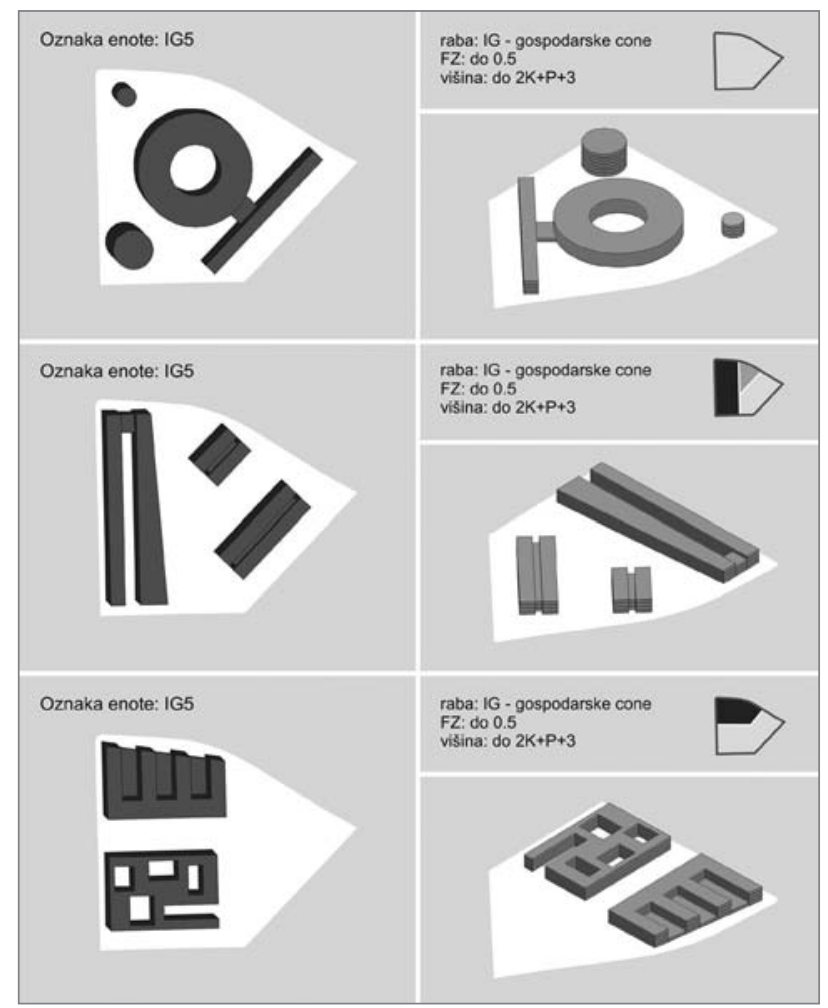

Slika 6: Regulacija logističnega središča in odprtost rešitev, ki jih omogoča taka regulacija (vir: Mlakar, 2008).

objekte $\mathrm{z}$ večjo prostornino, se območja industrije ter logističnih dejavnosti regulirajo $\mathrm{z}$ dovoljenim faktorjem zazidanosti in višino. Faktor izrabe je uporaben predvsem v tistih območjih, $\mathrm{v}$ katerih so predvideni objekti standardnih etažnosti (višina etaže $2,5-3,0 \mathrm{~m}$ in 3,0-3,5m). Območja centralnih dejavnosti imajo zato kombinacijo maksimalnega dovoljenega faktorja izrabe in etažnosti.

\subsection{Opredelitev prometne mreže}

Glede na stopnjo prometa, ki jo proizvajajo logistična središča, je strateško pomembno integracijo prometnih tovornih tokov določiti tako, da se predvidene učinke načrtovanih središč vključi v manjkajoče oziroma $z$ drugimi dokumenti predvidene ureditve prometne infrastrukture (Hesse, 2004). Pomen racionalne prometne mreže je temeljna domneva načrtovanja logističnih središč. Vodenje prometnic mora biti načrtovano tako, da so zagotovljene najkrajše in najhitrejše povezave od vstopa na območje do ciljnih postaj. Smiselna je ureditev ene ali dveh prometnic najvišje stopnje in obvozne ceste, iz katerih se nadalje cepijo ceste nižje stopnje oziroma dovozne ceste in dostopi. Klasifikacija cest omogoča diferenciacijo prometa ter omejevanje hrupa tovornega in tranzitnega prometa. Vloga in stopnja posamezne prometnice določata tudi način njene regulacije. Prometnice višje stopnje imajo v profil vključene hodnike za pešce in kolesarje ter tudi rezervacijo prostora za urejanje drevoredov. Znotraj posamezne prostorske enote ni potrebe po podrobnejši prometni mreži, saj je ta predmet investitorja oziroma števila objektov in lastniške strukture. Zadostuje predlog mogoče členitve. $S$ tem je omogočena večja mera fleksibilnosti glede združevanja ali cepitve prostorskih enot.

Na podlagi zasnov posameznih območij je bil za gospodarsko središce Feniks razvit modularni sistem, ki je zasnovan na podlagi mreže a/c $(100 \mathrm{~m} / 115 \mathrm{~m})$ in b/d $75 \mathrm{~m} / 100 \mathrm{~m}$. Zasnova mreže izhaja iz zahteve po še racionalni velikosti zemljišča, ki jo dopušča konfiguracija terena in upoštevane naravne danosti. Členitev posredno kaže na predlagano prometno režo.

Fleksibilnost zasnove dopušča poljubno drobitev oziroma povezovanje območij gradnje glede na predpisane dopustne dejavnosti in objekte po posameznih območjih. Posamezne enote so razdeljene na manjša območja so namenjena umestitvi načrtovanih objektov in ostalih ureditev. Območja se lahko med seboj združujejo na podlagi idejnih zasnov posameznih investitorjev. Omejena so z regulacijskimi linijami prometnic, tako da ima vsako območje omogočen vsaj en dostop in komunalni priključek.

\subsection{Opredelitev načina in stopnje komunalne opremljenosti}

Z vidika zasnove komunalne opremljenosti je najpomembnejša enotnost upravljanja komunalne infrastrukture, saj prav javni značaj infrastrukture zahteva enotnost pri načrtovanju in delovanju komunalne infrastrukture ter oskrbi posameznih objek-

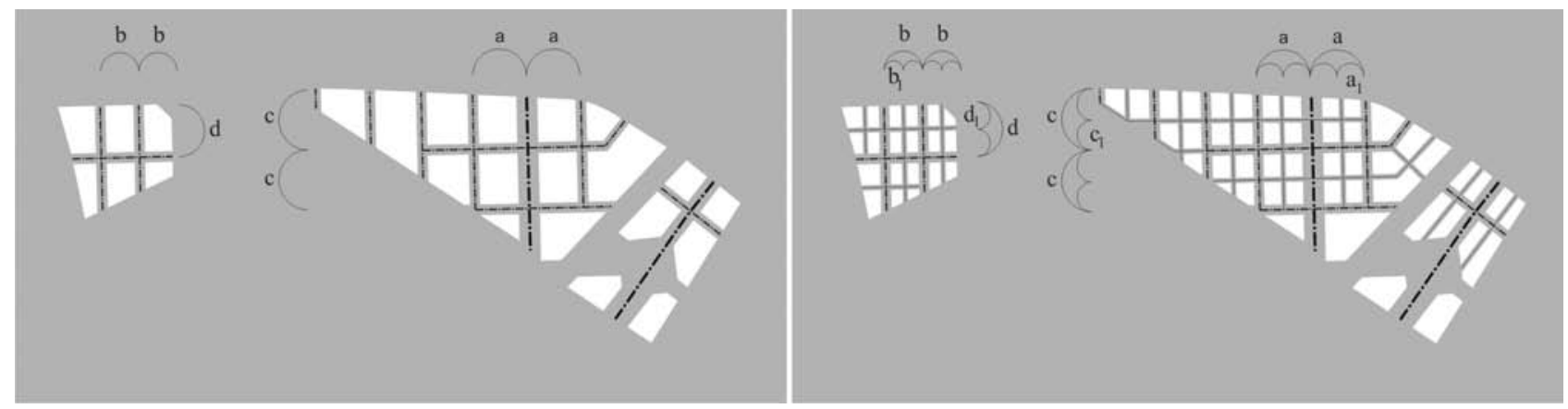

Slika 7: Predlagana mreža prometnic za gospodarsko središče Feniks (vir: Mlakar, 2008). 
tov. Kompleksnost prepletov dejavnosti v logističnem središču zahteva zgodnje načrtovanje komunalne oskrbe objektov.

Zato je treba že na najzgodnejši stopnji načrtovanja logističnih središč poskušati odgovoriti na ta vprašanja:

- kolikšna poraba pitne/tehnološke vode je potrebna za posamezno dejavnost/objekt/območje? Kako lahko to porabo zmanjšamo? Kje je lociran količinsko in kakovostno ustrezen vir;

- kakšne so zahteve za požarno varnost objektov in dejavnosti v njih ter kakšni viri oziroma možnosti za gašenje so na voljo na širšem območju;

- kakšne odpadne vode nastajajo na vsem območju logističnega središča in kakšne so njihove količine;

- ali obstajajo odvodniki odpadne vode ali pa je treba reševati problematiko zadrževanja in čiščenja voda na lokaciji;

- kakšne vrste odpadkov nastajajo na lokaciji; ali je mogoče odpadke iz specifičnih dejavnosti predelati na kraju samem;

- kakšne potrebe po ogrevanju in hlajenju ima posamezna dejavnost/objekt; kakšne temperaturne režime lahko pričakujemo;

- kakšni materiali in tehnologija gradnje bodo uporabljeni, da bo poraba energije čim nižja;

- kakšne potrebe po električni energiji ima posamezna dejavnost/objekt;

- ali obstajajo možnosti izrabe obnovljivih virov energije (državni pravilnik zahteva, da je $25 \%$ potrebne energije pridobljeno iz obnovljivih virov);

- kakšne upravljavske in finančne posledice imajo rešitve komunalne infrastrukture na logistično središče in uporabnike v njem.

Vsa vprašanja se tako strnejo $\mathrm{v}$ eno samo: kako zasnovati komunalno infrastrukturo in oskrbo z njo tako, da bodo stroški čim nižji, ob hkratni ustrezni in zadostni oskrbi ter čim manjši in čim učinkovitejši rabi dobrin?

\subsubsection{Posamezni vidiki načrtovanja okoljske infrastrukture}

Pri klasičnem pristopu $\mathrm{k}$ načrtovanju oskrbe $s$ pitno vodo se praviloma opredeli porabo pitne in tehnološke vode ter preveri razpoložljivost obstoječega vodovodnega omrežja $s$ količinskega vidika. Pri načrtovanju vodovodnega omrežja je treba sočasno reševati vprašanje zagotavljanja požarne vode. Tehnološki procesi posameznih dejavnosti v logističnem središču (predelava, skladiščenje) lahko pomenijo visoko požarno tveganje, zato je izvedba hidrantnega omrežja nujna. Če javno vodovodno omrežje ni sposobno zagotoviti zadostnih količin za požarno varstvo, je treba v logističnem središču zagotoviti prostor za skupni hranilnik požarne vode in izgradnjo hidrantnega omrežja za gašenje. Glede na razpoložljivost vira (pitne) vode oziroma upoštevajoč želene razbremenitve vodovodnega omrežja je smiselno preveriti možnost odvzema vode neposredno iz podtalja na lokaciji središča. Tudi potrebe po tehnološki vodi lahko zahtevajo večje količine vode, zato je priporočljiva uporaba zaprtih tehnoloških tokokrogov s ponovno uporabo vode in možnost zagotavljanja vode na lokaciji, lahko v kombinaciji z zajemom požarne vode.

Za zmanjšanje porabe pitne vode $\mathrm{v}$ smislu trajnostnega razvoja in manjše porabe virov obstajajo posamezni principi, ki so večinoma vezani na osveščenost uporabnikov. Pomemben element zmanjšanja porabe pa je možnost uporabe tako imenovane »sive « vode, torej vode, ki je že bila uporabljena, vendar pri tem ni prišla $\mathrm{v}$ stik $\mathrm{s}$ fekalijami in $\mathrm{z}$ njimi podobnimi snovmi. Sive vode se lahko v objektih uporabi za splakovanje stranišč in zalivanje zelenih površin središča. Tako se lahko del pitne vode povrne neposredno v podtalje in ne obremenjuje kanalizacijskih sistemov.

Pri odvajanju odpadne komunalne vode je najustreznejša rešitev priključitev na obstoječi kanalizacijski sistem in odvod odpadne vode na čistilno napravo v naselju. Ob morebitni oddaljenosti do kanalizacijskega omrežja je mogoče urediti tudi male čistilne naprave $\mathrm{v}$ središču. V skladu s trajnostnimi principi se priporoča izvedba bioloških čistilnih naprav, ki jih je mogoče tudi primerno vključiti v sistem zelenih in odprtih površin logističnih središč.

Gosta pozidava v logističnih središčih z velikim deležem tlakovanih površin pomeni zmanjševanje količine padavinske vode, ki pronica do podzemnih voda, povečano obremenitev kanalizacijskega omrežja in vodotokov ter povečanje nevarnosti poplav dolvodno. Pri tem gre zaradi visokih odtočnih koeficientov (deleža vode, ki se ga kanalizira $s$ površine $\mathrm{v}$ odvodnike) za veliko količino padavinske vode, ki jo je treba odvesti s teh površin. Za zmanjševanje in zakasnjevanje padavinskega odtoka se priporoča razpršeno zadrževanje vode na površini (strešni vrtovi), ponikanje na površini (zelenice, parkirišča s prepustnim tlakom), koncentrirano zadrževanje na površini (suhi ali mokri zadrževalniki vode, ki so lahko osnova krajinskih in parkovnih ureditev), koncentrirano zadrževanje pod površino (zadrževalni bazeni in kanali) in ponikanje pod površino (ponikalna polja, drenaže). Sodobni koncepti urbane odvodnje torej težijo $\mathrm{k}$ posnemanju naravnih procesov oziroma zadrževanju in ponikanju vode na kraju samem. Ena od posledic takšne prostorske politike je širok manevrski prostor za krajinsko oblikovanje in obsežne zelene površine v okolici večjih kompleksov poselitve, kar praviloma dviguje tudi kakovost bivalnega oziroma delovnega okolja. 


\subsubsection{Posamezni vidiki načrtovanja energetske infrastrukture}

V Sloveniji so bile s sprejemom Resolucije o nacionalnem energetskem programu postavljene osnove energetske oskrbe, ki temelji na rabi obnovljivih virov energije in njeni učinkoviti rabi. Glede na predpise je treba za vsak objekt, ki je velik več kot $1000 \mathrm{~m} 2$ (razen če ni za objekt način energetske oskrbe opredelil že lokalni energetski koncept ali drug predpis), izdelati študijo izvedljivosti alternativnih sistemov za oskrbo z energijo. Kot mogoči sistemi se štejejo:

- daljinsko ali skupinsko ogrevanje ali hlajenje, če je na voljo;

- toplotne črpalke;

- decentralizirani sistemi na podlagi obnovljivih virov energije;

- soproizvodnja toplote/hladu in elektrike.

$\mathrm{V}$ študiji energetske oskrbe se glede na podatke o potrebah po energiji za ogrevanje in hlajenje ter po električni energiji določi ustrezen oskrbni sistem. Najprimernejši način oskrbe logističnega središča je iz sistema daljinskega ogrevanja s toploto, iz katerega je mogoče proizvesti tudi hlad, vendar so daljinski sistemi vezani izrazito na mestna središča in so zato realne možnosti za priključitev pogosto majhne. Toplotne črpalke zagotavljajo le nizkotemperaturni režim ogrevanja, kar pa je za potrebe, kakršne imajo logistična središča, praviloma manj primerno.

Uporaba decentraliziranih sistemov na podlagi obnovljivih virov energije je prostorsko pogojena. Izkoriščanje vetrne energija je v logističnih središčih zaradi obsežnosti vetrnih naprav dokaj težavno. Izraba geotermalne energije je priporočljiva predvsem na območjih z izrazitim geotermalnim potencialom, pri čemer je ta vir (tako kot pri ostalih toplotnih črpalkah) primernejši za oskrbo manjših objektov in območij. Uporaba lesne biomase je primerna predvsem na območjih, na katerih $s$ centralno energetsko enoto proizvajamo toploto, pomembno pa je, da so zagotovljene ustrezne površine za proizvodno enoto in zalogovnik goriva. Zaradi tipologije so objekti v logističnih središčih izrazito primerni za postavitev fotovoltaičnih elementov za izrabo sončne energije, pri katerih je sicer začetna investicija visoka, vendar se jo s proizvodnjo električne energije in prihranki v življenjski dobi povrne. Pri sončni energiji moramo upoštevati še več drugih možnosti, od sistemov za pasivno ogrevanje objektov s pravilno izvedbo pročelij in stenskih elementov do solarnih elementov za pripravo tople vode.

Pri soproizvodnji toplote/hladu in električne energije (ko- in trigeneracija) se v čim večji meri izkoristi primarno energijo pogonskega goriva in proizvede maksimalno količino toplote in električne energije, $\mathrm{z}$ vključitvijo absorpcijskih hladilnikov pa tudi hladu. Ekonomičnost tega sistema se kaže predvsem tam, kjer obstajajo dovolj velike potrebe po toploti, hladu in električni energiji. Izkazalo se je, da so logistična središča primerna prav za to obliko oskrbe z energijo, saj energijo izkoriščajo za ogrevanje v zimskem času, hlajenje v letnem času ter za pripravo tople sanitarne vode in proizvodnjo električne energije vse leto. Osnovni energent je praviloma zemeljski plin. Takšna ureditev zahteva namestitev centralne proizvodne enote, iz centralnega obrata za proizvodnjo toplote/hladu/elektrike pa se razpelje razvejano vročevodno in hladnovodno omrežje do posameznih objektov.

\section{Upravljanje}

Načrtovanje logističnih središč se ne sme končati s sprejetjem prostorskega izvedbenega akta. Za zagotovitev prostorsko in okoljsko sprejemljive vzpostavitve ter delovanja logističnega središča je smiselno zagotoviti celovito upravljanje in vzdrževanje območja gospodarskega središča, ki naj obsega najmanj:

- razmeščanje podjetij, upoštevajoč njihove prostorske potrebe, predvidene dejavnosti in pričakovane vplive na okolje ter racionalno izgradnjo območja v več stopnjah;

- koordinacijo priprave projektne dokumentacije in sodelovanje v postopkih s področja graditve objektov, komunalnega opremljanja zemljišč in varstva okolja;

- presojo ustreznosti posameznih projektnih rešitev tako, da se zagotovi oblikovna in funkcionalna skladnost gospodarskega središča ter ustrezna opremljenost $s$ komunalno in z energetsko infrastrukturo;

- presojo okoljske sprejemljivosti posameznih predvidenih dejavnosti tako, da se preprečijo morebitni čezmerni vplivi na okolje in zagotovi ustrezno delovno okolje;

- enotno vodenje evidenc s področja evidentiranja nepremičnin in varstva okolja;

- vzdrževanje prometne in komunalne infrastrukture ter elektronskih komunikacij;

- vzdrževanje odprtih zelenih površin;

- ravnanje z odpadki;

- varstvo pred naravnimi in drugimi nesrečami;

- izvajanje oziroma usklajevanje trajnega spremljanja in

- izvedbo oziroma usklajevanje izvedbe dodatnih zaščitnih ukrepov, ki se izvedejo na podlagi rezultatov trajnega spremljanja.

\section{Sklep}

Prostorsko in okoljsko načrtovanje logističnih središč se $\mathrm{v}$ osnovi ne razlikuje od načrtovanja ostalih prostorskih ureditev. $\mathrm{Za}$ uspešnost načrtovanja je najpomembnejša postavitev ciljev, ki se morajo nanašati na vse vidike razmišljanja o prihodnosti prostora. Dolžnost prostorskega načrtovanja je, da 
med pripravo načrta smiselno uskladi varovalne in razvojne vidike oziroma posamezne interese $\mathrm{v}$ prostoru ter jih poveže $\mathrm{v}$ prepoznavne, učinkovite in kakovostne prostorske ureditve. Pri tem je za uspešnost presoje ustreznosti te uskladitve zelo pomembno, da je predlog logističnega centra izoblikovan na osnovi transparentne analize in podan kot izbirne možnosti. Negotovost o sprejemljivosti posega v družbi je mogoče preseči le, če vemo, da drugih oziroma boljših možnosti uresničitve tega posega ni na voljo.

Cilji prostorskega razvoja se morajo jasno izraziti v prostorskem konceptu, ki se v prostorskem aktu - prek regulacijskih elementov urejanja prostora in varstva okolja (rabe, izrabe, gabaritov, pogojev varstva okolja ...) - formalizira v pravice in dolžnosti na določenem delu zemljišča. Zelo pomembno je sodelovanje $\mathrm{z}$ javnostmi, ki naj teži $\mathrm{k}$ ustvarjanju skupnih ciljev in razvoju usklajenih rešitev.

Jure Zavrtanik, univ. dipl. inž. arh.

LUZ, d. d., Ljubljana, Slovenija

E-pošta: jure.zavrtanik@luz.si

Dr. Aleš Mlakar, univ. dipl. inž. kraj. arh.

Univerza v Ljubljani, Biotehniška fakulteta, Oddelek za krajinsko

arhitekturo, Ljubljana, Slovenija

E-pošta: ales_mlakar@siol.net

Marko Fatur, univ. dipl. inž. grad.

LUZ, d. d., Ljubljana, Slovenija

E-pošta: marko.fatur@luz.si

\section{Viri in literatura}

Bina, O. (2001): Strategic environmental assessment of transport coridors: Lessons learned comparing the methods of five member states. London, European Commission, DG Environment, Environmental Resources Management.

Canadian Environmental Assessment Agency (1996): The Canadian environmental assessment act. Reference guide on physical and cultural heritage resources. Ottawa, Canada.

Campbell, S., in Fainstein, S. S. (1998): Introduction: The structure and debates of planning theory. V: Campbell, S., in Fainstein, S.S. (ur): Readings in planning theory, str. 1-14. Malden, Blackwell Publishers Inc.

Chechile, R. A., in Carlisle, S. (ur.) (1991): Environmental decision making: A multidisciplinary perspective. New York, Van Nostrand Reinhold.

European Commission (2003): Implementation of Directive 2001/42 on the Assessment of the effects of certain plans and programmes on the environment. Luxembourg, Office for Official Publications of the European Communities.

Free University of Brussels - IGEAT (2006): Espon project 3.2. Spatial scenarios and orientations in relation to the ESDP and cohesion polic: Teritorial impact assessment. Final report. Volume 5. Bruxelles.
Gajšek, M. (2000): Prostorsko planiranje in omrežje mest v Sloveniji: Kako prometno-logistični terminali in podjetniške cone spodbujajo razvoj mest. Urbani izziv, 11(1), str. 27-33.

Hesse, M. (2004): The transport geography of logistics and freight distribution. Journal of Transport Geography, 12(3), str. 171-184.

Hesse, M. (2008): The city as a terminal: The urban context of logistics and freight transport. Farnham, Ashgate.

Lyle, J. T. (1985): Design for human ecosystems. New York, Van Nostrand Reinhold.

Marušič, J. (1993): Optimizacijski postopki kot sredstvo za vključevanje varovalnih presoj v celokupno in z okoljem skladno prostorsko načrtovanje. Ljubljana, Univerza v Ljubljani, Biotehniška fakulteta, Katedra za krajinsko arhitekturo.

Mlakar, A. (2006): Možnosti zmanjševanja negotovosti v prostorsko načrtovalnih postopkih. Doktorska disertacija. Ljubljana, Univerza v Ljubljani, Biotehniška fakulteta.

Mlakar, A. (ur.) (2008): Državni prostorski načrt za gospodarsko središče Feniks v Posavju. Dopolnjen osnutek. Ljubljana, LUZ d.d., Ministrstvo za gospodarstvo, Ministrstvo za okolje in prostor, Direktorat za prostor.

Nared, J. (2007): Model razporeditve pričakovanih delovnih mest kot instrument za načrtovanje in vrednotenje projektov: primer Resolucije o nacionalnih razvojnih projektih za obdobje 2007-2023. V: Nared, J., Perko, D., Ravbar, M., Horvat, A., Hren, M., Juvančič, L., idr. (ur.): Regionalni razvoj 1: Veliki razvojni projekti in skladni regionalni razvoj. Ljubljana, Založba ZRC, ZRC SAZU.

Nooteboom, S. (1999): Environmental assessments of strategic decisions and project decision: Interactions and benefits. DHV Environment and Infrastructure Publication of the Ministry of Housing, Spatial Planning and the Environment, The Netherlands.

Plut, D. (2007): Sonaravna ocena nacionalnih razvojnih projektov Slovenije (2007-2023). V: Nared, J., Perko, D., Ravbar, M., Horvat, A., Hren, M., Juvančič, L., idr. (ur.): Regionalni razvoj 1: Veliki razvojni projekti in skladni regionalni razvoj. Ljubljana, Založba ZRC, ZRC SAZU.

Radej, B. (2008): Sinteza vplivov nacionalnega energetskega programa na prostorsko kohezijo Slovenije: Delovni zvezek št. 2. Ljubljana, Slovensko društvo evalvatorjev.

Taylor, P. W. (1986): Respect for nature. Princeton, Princeton University Press.

Zavodnik Lamovšek, A., Hudoklin, J., Peterlin, M., in Mlakar, A. (2008): Priprava strokovnih osnov za oblikovanje metodologije vrednotenja in medsebojne primerjave različic v postopkih priprave $d r$ žavnega prostorskega načrta s prostorskega in urbanističnega vidika. Ljubljana, Univerza v Ljubljani, Fakulteta za gradbeništvo in geodezijo, Ministrstvo za okolje in prostor, Direktorat za prostor. 